\title{
Diallel analysis of popcorn populations for yield, popping expansion and resistance to fall armyworm
}

\author{
Edicarlos Peterlini ${ }^{1}$, Ronald José Barth Pinto ${ }^{l}$, Carlos Alberto Scapim ${ }^{1}$, Diego Ary Rizzardi ${ }^{1}$, \\ Filipe Augusto Bengosi Bertagna ${ }^{1 *} \mathbb{1}$, Antônio Teixeira do Amaral Júnior ${ }^{2}$
}

10.1590/0034-737X202067040006

\begin{abstract}
The objective of this study was to estimate the varietal and heterotic effects related to grain yield, popping expansion and resistance of popcorn against fall armyworm. Twelve open-pollinated varieties were intercrossed in a complete diallel mating scheme. The 66 experimental hybrids, together with their parents and controls Zapalote Chico, BRS 1030 and IAC 125, resulted in a total of 81 treatments, evaluated in an experiment in a 9x9 triple-square lattice design, in Maringá-PR and Araruna-PR. The data were analyzed according to the diallel model of Gardner and Eberhart (1966). The following traits were evaluated: grain yield (GR); mean plant height $(\mathrm{PH})$ and insertion height of the highest ear in the stem (EI); silking (SIL); final plant density (FD) and popping expansion (PE). Variety PR 023 is indicated for intrapopulation improvement for grain yield. Regarding popping expansion, the results indicated cross SAM x UNB 2U C5 for recurrent reciprocal selection. In relation to resistance to fall armyworm, the varieties PARA 172, PA 091, PR 023, and SE 013 were selected for intrapopulation improvement. On the other hand, the crosses PARA 172 x BOZM 260, PA 091 x BOYA 462 and SAM x UNB $2 \mathrm{U}$ C5 can be indicated for interpopulation improvement.
\end{abstract}

Keywords: Zea mays L.; specialty corns; Spodoptera frugiperda; additive effects; heterosis.

\section{INTRODUCTION}

Popcorn (Zea mays L.) is a popular and widely consumed food in Brazil. Nevertheless, commercial cultivation is modest, as a consequence of the lack of high quality genotypes, unlike in the case of common corn (Zea mays L.). However, consumption has increased in Brazil over the years, making the crop attractive to farmers (Paula et al., 2010; Moterle et al., 2012; Gonçalves et al., 2014).

Studies emphasize that popcorn cultivation is underdeveloped, given the market potential of this crop (Arnhold et al., 2009). The development of cultivars with desirable traits, such as better plant health and high grain yield, is fundamental to promote popcorn cultivation. Other important factors in popcorn breeding are aspects related to quality, such as grain texture and softness. The establishment of cultivars that unite the desirable agronomic traits with a high popping expansion is one of the greatest difficulties in popcorn breeding (Moterle et $e t$ al., 2012; Gonçalves et al., 2014).

In view of the scarcity of popcorn cultivars, particularly hybrid cultivars, breeding at the intra- and interpopulational level are alternatives in the development of new varieties (Scapim et al., 2010; Moterle et al., 2012). To this end, the estimation of genetic parameters and of variance components of the populations under study is extremely important to maximize genetic gains in breeding programs (Scapim et al., 2010; Hallauer et al., 2010).

Maize is attacked by various pests during almost the entire crop cycle. In particular, fall armyworm (Spodoptera frugiperda) is considered the main pest of the crop, for causing damages that can cause up to $60 \%$ yield losses, aside from facilitating disease infection (Santos et al., 2004; Farias et al., 2014). These losses also occur in popcorn.

\footnotetext{
Submitted on August 7th, 2019 and accepted on June 28 $8^{\text {th }}, 2020$.

${ }^{1}$ Universidade Estadual de Maringá, Departamento de Agronomia, Maringá, Paraná, Brazil. edicarlospeterlini@gmail.com; rjbpinto@uem.br; cascapim@uem.br; rizzardiary@gmail.com; filipeabbertagna@gmail.com

${ }^{2}$ Universidade Estadual Norte Fluminense Darcy Ribeiro, Departamento de Agronomia, Campos dos Goytacazes, Rio de Janeiro, Brazil. amaraluenf@gmail.com *Corresponding author: filipeabbertagna @gmail.com
} 
The resistance of maize to fall armyworm has been thoroughly studied and a series of resistant genotypes were developed (Ni et al., 2011). The introgression of native resistance into commercial hybrids can increase durability and confer additional tolerance to other stresses, e.g., disease, heat and drought (Farias et al., 2014).

However, with regard to popcorn cultivation, information is scarce. In this context, research that addresses the identification of genotypes with resistance to pests and other desirable agronomic traits must be conducted, with a view to reducing production costs.

Diallel analysis represents one of the most appropriate genetic-statistical techniques for estimating genetic parameters, e.g., the additive and non-additive effects involved in the control of the traits of interest, as a support for decision making in breeding. In addition, diallel mating designs provide information on combining ability, classification of heterotic groups, heterotic effects and hybrid development. Thus, this method allows the selection of the best lines, increasing the efficiency and making the development of hybrids more practical (Cai et al., 2012; Gonçalves et al., 2014).

This study estimated the varietal and heterotic effects related to grain yield, popping expansion and resistance of popcorn to fall armyworm.

\section{MATERIALAND METHODS}

The study was divided in two stages: I) hybrid development and seed multiplication of the parents; II) evaluation experiments for the intervarietal hybrids and their parents.

The first stage occurred in the 2014/2015 growing season, when the 66 intervarietal hybrids were established, by crosses between the 12 varieties used and the simultaneous multiplication of the parent varieties (Table 1).
After the crosses and seed multiplication of the parents, two field experiments were installed in the second season of 2015, the first in Maringá-PR (latitude $23^{\circ} 25^{\prime} \mathrm{S}$; longitude $51^{\circ} 57^{\prime} \mathrm{W}$ ); $550 \mathrm{~m}$ asl, and the second in Araruna - PR (latitude $23^{\circ} 52^{\prime}$ S ; longitude $52^{\circ} 32^{\prime} \mathrm{W} ; 510 \mathrm{~m}$ asl). The soil at both sites is classified as Dystrophic Red Latosol. All cultural operations were performed according to official recommendations for second season maize (Cruz et al., 2006).

The following traits were evaluated: a) grain yield (GR), $\mathrm{kg} \mathrm{ha}^{-1}, \mathrm{~b}$ ) mean plant height $(\mathrm{PH})$ and insertion height of the highest ear in the stem (EI) in cm; c) silking (SIL), in days; d) final plant density (FD) and e) popping expansion (PE), calculated as the ratio between expanded popcorn volume and raw grain weight (in $\mathrm{mL} \mathrm{g}^{-1}$ ). For each plot, a 30 $\mathrm{g}$ grain sample was popped in an electric popper, with automatic temperature control, set at $280^{\circ} \mathrm{C}$, developed by Embrapa-National Center for Research and Development of Agricultural and Livestock Instrumentation (CNPDIA). The expanded popcorn volume was measured in a 2,000 $\mathrm{mL}$ graduated beaker. The grains for popping were taken from the central basal part of the ears, with a moisture content between 12.5 and 13.5\% (Luz et al., 2005).

Fall armyworm resistance (FAR) was also evaluated, induced by natural infestation. The 15 central plants of each plot were evaluated 14, 21, 28 days after plant emergence (DAE). The assessments were graded by scores on a visual damage scale, with damage scores ranging from 1 to 9, adapted from Davis et al. (1992).

After data collection, the grain yield values were corrected using the covariance analysis methodology, as proposed by Vencovsky and Cruz (Cruz et al., 2012). The experiments were planted in a $9 \times 9$ square, partially balanced, triple lattice design with three replications. The experimental plot consisted of two 7-m rows, with plants spaced $0.20 \mathrm{~m}$ apart and rows $0.90 \mathrm{~m}$. Planting density was 55.555 plants ha-1.

Table 1: List of open-pollinated populations used as parents

\begin{tabular}{lccc}
\hline \multirow{2}{*}{ Genotype } & \multicolumn{2}{c}{ Caryopsis } & \multirow{2}{*}{ Origin } \\
\cline { 2 - 3 } & Pericarp & Endosperm & CIMMYT \\
\hline ARZM 13050 & Colorless & Write and Yellow & CIMMYT \\
URUG 298-Roxo & Red & Orange & South America/USA \\
SAM* & Colorless & Orange & CIMMYT \\
PARA 172 & Colorless & Write and Yellow & CIMMYT \\
ARZM 07049 & Colorless & Orange & UENF \\
UNB 2U C5 & Colorless & Orange & UEM \\
SE 013 & Colorless & Write and Yellow & UFV \\
VIÇOSA & Colorless & Orange & CIMMYT \\
BOZM 260 & Colorless & Write & UEM \\
PR 023 & Colorless & Orange & UEM \\
PA 091 & Colorless & Yellow & CIMMYT \\
BOYA 462 & Colorless & Colorless and Black/Purple & \\
\hline
\end{tabular}

*South American Mushroom. 
Prior to the analysis of variance for each trait, the basic assumptions for normality and homogeneity of error variances were checked by the Shapiro-Wilk and Bartlett tests, respectively.

The data for each trait and site were analyzed based on the general mathematical-statistical model for lattice design, with recovery of the interblock information, to obtain the variance of the effective error and adjusted means, using software SAS 9.3. In this model, the treatment effect was defined as fixed and the other effects as random.

For the analysis of combined variance between environments, the homogeneities of the effective variances of each variable between the two environments were analyzed by the Hartley test.

The mathematical-statistical model for the combined analysis of data variance was

$\mathrm{Y}_{\mathrm{ijkl}}=\mu+\mathrm{G}_{\mathrm{i}}+\mathrm{E}_{\mathrm{j}}+\mathrm{GE}_{\mathrm{ij}}+\mathrm{R}_{\mathrm{k}}+\mathrm{R} / \mathrm{E}_{\mathrm{k}(\mathrm{j})}+\mathrm{B} / \mathrm{R} / \mathrm{E}_{\mathrm{l}(\mathrm{k}) \mathrm{j})}+\mathrm{R}_{\mathrm{k}}+\mathrm{R} / \mathrm{E}_{\mathrm{k}(\mathrm{j})}$ $+\mathrm{B} / \mathrm{R} / \mathrm{E}_{\mathrm{l}(\mathrm{k})(\mathrm{j})}+\varepsilon_{\mathrm{ijkl}}$,

where: $\mathrm{Y}_{\mathrm{ijkl}}=$ the observation in the ith genotype in the jth environment in the kth replication in the lth block, $\mu=$ the overall mean, $\mathrm{G}_{\mathrm{i}}=$ the fixed effect of ith genotype, $\mathrm{E}_{\mathrm{j}}=$ the fixed effect of $\mathrm{jth}$ environment, $\mathrm{GE}_{\mathrm{ij}}=$ the fixed interaction effect of the ith genotype with $\mathrm{jth}$ environment, $\mathrm{R}_{\mathrm{k}}=$ the random effect of the kth replication, $\mathrm{R} / \mathrm{E}_{\mathrm{k}(\mathrm{j})}=$ the random effect of the kth replication within $\mathrm{jth}$ environment, $\mathrm{B} / \mathrm{R} / \mathrm{E}_{\mathrm{l}(\mathrm{k})(\mathrm{j})}=$ the random effect of the lth block within kth replication within jth environment, and $\varepsilon_{\mathrm{ijkl}}=$ the residual error where $\varepsilon_{\mathrm{ijk}} \sim \operatorname{NID}\left(0, \sigma^{2}\right)$.

The combined analysis of variance between the environments provided the adjusted means, with recovery of the individual interblock information.

The combined diallel analysis of the experiments was performed as proposed by Gardner and Eberhart (1966), using the mathematical-statistical model (Morais et al., 1991)

$\mathrm{Y}_{\mathrm{ijk}}=\mathrm{m}+\left(\vartheta_{\mathrm{i}}+\vartheta_{\mathrm{j}}\right) / 2+\mathrm{a}_{\mathrm{k}}+\left(\vartheta \mathrm{a}_{\mathrm{ik}}+\vartheta_{\mathrm{jk}}\right) / 2+\theta\left(\overline{\mathrm{h}}+\overline{\mathrm{h}} \mathrm{a}_{\mathrm{k}}+\right.$ $\left.+h_{i}+h a_{i k}+h_{j}+h a_{j k}+s_{i j}+s a_{i j k}\right)+\bar{\varepsilon}_{i j k}$,

where: $Y_{i j k}=$ the observation of the combination between ith genotype with jth in the kth environment, $\vartheta_{i}, \vartheta_{j}$ and $\vartheta a_{i k}, \vartheta a_{j k}=$ varietal effect of the ith and jth genotype and them respectively interactions with kth environment, and $\overline{\mathrm{h}} \mathrm{a}_{\mathrm{k}}=$ the effect of the mean heterosis and its interaction with kth environment, $h_{i}, h_{j}$ and $h a_{i k}$, ha ${ }_{j k}=$ the varietal heterosis effect of the ith and jth genotype and respectively them interactions with $\mathrm{kth}$ environment, $\mathrm{s}_{\mathrm{ij}}$ and $\mathrm{sa}_{\mathrm{ijk}}=$ the specific heterosis between ith e jth genotype combination and its interaction with kth environment, $\bar{\varepsilon}_{\mathrm{ijk}}=$ the residual mean error. The diallel analysis was performed with software Genes (Cruz, 2016). All the analysis were made considering probability $\alpha=5 \%$.

\section{RESULTS AND DISCUSSION}

All main effects and their interactions were significant $(p<0.05)$ for yield, plant height, ear insertion height, silking, and popping expansion, indicating differences in the evaluated genotypes (Table 2). The data showed a significant effect $(\mathrm{p}<0.05)$ of the genotype $\times$ environment $(\mathrm{G} \times \mathrm{E})$ interaction, evidencing the differentiated performance of the genotypes in the studied environments. Therefore, the evaluations of the selection procedures of promising genotypes should be environment-specific, rather than addressing the entire set of environments.

In a study using diallel analysis for 16 maize populations adapted to the Corn Belt region, Laude and Carena (2014) found highly significant effects of the $\mathrm{G} x \mathrm{E}$ interaction for traits related to grain yield and quality. In a diallel analysis of tropical maize genotypes, Moterle et al. (2012) found a significant $\mathrm{G}$ x E effect for all evaluated agronomic traits.

The treatment effects were significant for all variables ( $p<0.05$ ) by the F test, indicating differences among the hybrids. The results of the combined diallel analysis indicated significant varietal effects $(\mathrm{p}<0.05)$ for all variables (Table 2), indicating that the parents do not constitute a homogeneous group. The results evidenced the predominance of additive genetic effects, which are important in plant breeding. For the variables $\mathrm{PH}$, ear height and GY, Kvitschal et al. (2004) found similar results. Similar observations for $\mathrm{PH}$, insertion height of the first ear and GY were reported by Moterle et al. (2012), in a combining ability analysis by the Griffing method.

In relation to the main heterotic effects and their interactions for the parents and their interpopulation hybrids (Table 2$)$, there was a significant effect $(\mathrm{p}<0.05)$ for all variables, evidencing that dominance also affected trait inheritance of the analyzed traits, which can be exploited in breeding for superior hybrids.

The effects of the variety $\times$ environment interaction $(\mathrm{V} \times \mathrm{E})$ were significant $(\mathrm{p}<0.05)$ for all evaluated agronomic traits except plant height $(\mathrm{p}>0.05)$. This indicated that the genotypes should be individually selected based on their additive effects, in each environment, except for plant height, for which genotypes can be selected from the data of both environments.

The effects of heterosis $\times$ environment interaction $(\mathrm{H} \times \mathrm{E})$ were significant $(\mathrm{p}<0.05)$ for all agronomic traits except popping expansion $(p>0.05)$. The partitioning of Varietal Heterosis x Environment and Specific Heterosis x Environment contributed to the understanding of the effects of these interactions on grain yield. For plant height, the $\mathrm{H}$ x E interaction was fully explained by the Mean Heterosis x Environment interaction, different from the insertion height of the first ear. For trait PE, the main effect estimated by the $\mathrm{H} \times \mathrm{E}$ 
Table 2: Analysis of variance of the diallel variance, adapted by the Gardner and Eberhart model (1966) to estimate the effects of varieties and heterosis on grain yield (GY), plant height (PH), highest ear insertion height (EI), silking (SIL), popping expansion (PE), and diallel analysis for fall armyworm damage at 14 and 21 days after seedling emergence (DAE)

\begin{tabular}{|c|c|c|c|c|c|c|c|c|c|}
\hline \multirow{2}{*}{ S.V. ${ }^{1}$} & \multirow{2}{*}{ D.F. } & \multicolumn{5}{|c|}{ MS } & \multirow{2}{*}{ D.F. } & \multicolumn{2}{|c|}{ MS } \\
\hline & & GY & $\mathbf{P H}$ & EI & SIL & PE & & 14DAE & 21DAE \\
\hline Genotypes & 77 & $0.990 *$ & $1109.339 *$ & $1348.449 *$ & $66.982 *$ & $272.294 *$ & 77 & $0.5801 *$ & $0.4584 *$ \\
\hline Varieties & 11 & $1.986^{*}$ & $3249.043^{*}$ & $6142.523 *$ & $400.158^{*}$ & $1749.126^{*}$ & 11 & $1.3597 *$ & $1.0304 *$ \\
\hline Heterosis & 66 & $0.824 *$ & $752.721 *$ & $549.437 *$ & $11.452^{*}$ & $26.155^{*}$ & 66 & $0.4502 *$ & $0.3631 *$ \\
\hline H. $M$. & 1 & $31.024 *$ & $29405.392 *$ & 19305.004* & $161.887^{*}$ & $33.577^{*}$ & 1 & $0.0975^{\mathrm{ns}}$ & $3.9573 *$ \\
\hline H. V. & 11 & $0.327 *$ & $351.408^{*}$ & $299.519 *$ & $3.750 *$ & $32.963 *$ & 11 & $0.3428^{\mathrm{ns}}$ & $0.1888^{\mathrm{ns}}$ \\
\hline H.S. & 54 & $0.366^{*}$ & $303.865 *$ & $253.021 *$ & $10.235^{*}$ & $24.631 *$ & 54 & $0.4786^{*}$ & $0.3321^{\mathrm{ns}}$ \\
\hline Environments & 1 & $2.546^{*}$ & $317179.72 *$ & 169521.907* & $4867.510 *$ & $2.044^{\mathrm{ns}}$ & - & - & - \\
\hline $\mathrm{G} \times \mathrm{E}$ & 77 & $0.253^{*}$ & $163.599 *$ & $125.914 *$ & $5.541 *$ & $16.833^{*}$ & - & - & - \\
\hline $\mathrm{VxE}$ & 11 & $0.668^{*}$ & $82.064^{\mathrm{ns}}$ & $154.936^{*}$ & $13.635^{*}$ & $21.630 *$ & - & - & - \\
\hline $\mathrm{HxE}$ & 66 & $0.184 *$ & $177.188^{*}$ & $121.077^{*}$ & $4.192 *$ & $16.033^{\text {ns }}$ & - & - & - \\
\hline H.M. $x E$ & 1 & $0.004^{\mathrm{ns}}$ & $3328.297 *$ & $1297.937 *$ & $23.802 *$ & $0.189^{\text {ns }}$ & - & - & - \\
\hline H.V. $x E$ & 11 & $0.341 *$ & $161.881^{\mathrm{ns}}$ & $155.733^{*}$ & $2.297^{\mathrm{ns}}$ & $13.320^{\mathrm{ns}}$ & - & - & - \\
\hline H.S. $x E$ & 54 & $0.156^{*}$ & $121.953^{\mathrm{ns}}$ & $92.224^{\mathrm{ns}}$ & $4.215^{*}$ & $16.880^{*}$ & - & - & - \\
\hline Effective error & 272 & 0.094 & 113.405 & 83.361 & 1.729 & 7.630 & 136 & 0.2732 & 0.2552 \\
\hline Mean & - & 1.851 & 217.306 & 137.806 & 59.202 & 18.328 & - & 4.0089 & 6.0735 \\
\hline
\end{tabular}

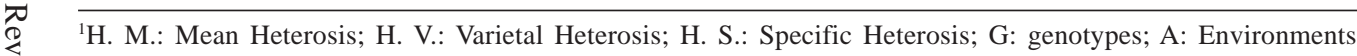

*: significant, by the $\mathrm{F}$ test, at $5 \%$ probability; ns: not significant, by the $\mathrm{F}$ test, at $5 \%$ probability.

$$
\text { क data not shown. }
$$


interaction was not significant, but the significance of the mean square for Specific Heterosis x Environment ( $\mathrm{p}<$ 0.05 ) indicated that the non-additive effects for this trait differed between the environments.

The estimates of $\hat{\vartheta}_{i}$, were derived from the combined diallel analysis, by model 4 of the method proposed by Gardner and Eberhart (1966), for the five traits evaluated in both environments (Table 3 ). The $\hat{\vartheta}_{i}$ estimates were similar to the $\hat{g}_{i}$, effects (general combining ability - GCA), since a part of the GCA effects are due to varietal effects and another part due to effects of varietal heterosis (Kvitschal et al., 2004). In the comparison of the values, the estimates with two-fold respective values of the standard deviation were considered the best (Cruz et al., 2012).

In Maringá, the $\hat{\vartheta}_{i}$ effects for GY were significantly higher for the varieties UNB 2U C5 and PR 023, which did not differ from the varieties PARA 172 and BOYA 462, while in Araruna, only variety PR 023 had higher GY estimates. In Araruna, PR 023 and ARMZ 13050 performed better than all the others, except VIÇOSA and BOZM 260, with positive and similar estimates of varietal effects and the best per se performances.

In the case of plant height, ear insertion height and cycle length, the lowest estimates are generally the most interesting for breeding. According to Rangel et al. (2011), tall plants are more prone to lodging and breaking, which is aggravated in regions with high incidence of strong winds. Therefore, for plant height, the selection of plants with lower values is interesting. A shorter cycle length facilitates an optimized exploitation of the areas by different crops in rotation and a greater chance of phytosanitary stability and frost resistance, which is essential in second season crops (Bolson et al., 2016).

The parents URUG 298-Roxo, ARMZ 13050 and VIÇOSA had negative $\hat{\vartheta}_{i}$ estimates and a good per se performance, indicating them for breeding for a lower plant and ear-insertion height, in both environments, without significant differences from each other. The genotypes PA 091 and ARMZ 07049 in Maringá, and genotypes PARA 172 and UNB 2U C5 in Araruna were also noteworthy, significantly similar to those mentioned above. The varieties with negative estimates for silking and therefore earlier cycles were URUG 298-Roxo, ARMZ 13050 and UNB 2U C5.

Analogously to the trait cycle length, the performance of the varieties for PE differed between the environments. The varieties with the significantly best per se performances, based on the $\hat{\vartheta}_{i}$ estimates, were UNB 2U C5 and SAM in Araruna and UNB 2U C5 in Maringá. Another promising genotype for intrapopulation improvement was parent VIÇOSA, although significantly inferior to UNB 2U C5 in Maringá and the genotypes UNB 2U C5 and SAM in Araruna.
The significant effects of the mean squares of mean heterosis for all traits indicated genetic divergence among the studied parent lines. Thus, this situation is favorable for breeding, by the exploitation of heterotic effects in hybrids (Kvitschal et al., 2004).

The best varieties, with positive heterotic effects on grain yield in crosses were ARMZ 07049 and BOYA 462, not differing from PARA 172 and SAM in Araruna. PARA 172 was particularly interesting for having the highest estimates of varietal heterosis, indicating a wide divergence from the other varieties, being recommended for the exploration in breeding for hybrid synthesis. The performance was significantly poorer only for crosses involving UNB 2U C5 and PR 023 in Maringá and VIÇOSA, ARMZ 13050 and UNB 2U C5 in Araruna.

The varieties with particularly good (i.e., negative) estimates of PH, EI and SIL were ARMZ 13050 and UNB $2 \mathrm{U}$ C5, in both environments. Thus, they are suitable to breed plants for the establishment of earlier and short hybrids.

The variety associated to crosses with particularly high heterotic effects for PE was PR 023, which was similar to PA 091, ARMZ 13050, VIÇOSA, PARA 172, and UNB 2U C5 (Table 2). Therefore, these are promising varieties for the breeding of lines to be used in the future for the development of hybrids in popcorn breeding programs.

The high PE observed in variety SAM was predominantly due to effects of additive action genes. In relation to the varieties UNB 2U C5 and VIÇOSA, apart from the additive effects explaining the high PE performance, there was also a positive heterotic effect. The presence of both effects suggests that these varieties are not only indicated for intrapopulation, but also for interpopulation improvement, aiming at the exploration of the heterotic effects. According to Gonçalves et al. (2014), the choice of parents for the formation of segregating populations based on the combining ability and the presence of complementary genes are the chief factors for the success of a breeding program.

For landrace popcorn populations, Solalinde et al. (2014) also found evidence of heterosis, indicating that genetic gains for PE by interpopulation improvement are possible. The traits GY and PE rarely have simultaneous positive effects for $\hat{\vartheta}_{i}$ and $\hat{h}_{i}$, confirming the negative correlation between them.

In the GY analysis, a differentiated performance of some interpopulation hybrids was observed, based on specific heterosis estimates, e.g., VIÇOSA x BOYA 462 (0.692), URUG 298-Roxo x BOZM 260 (0.577), ARMZ 13050 x SE 013 (0.573) and BOZM 260 x BOYA 462 (0.510) in Maringá, with significantly higher estimates $(0.489$ to 0.238$)$ of specific heterosis, together with 10 other hybrids. On the other hand, in Araruna, the combinations were more 
Table 3: Estimates of variety $\left(\hat{\vartheta}_{i}\right)$, varietal heterosis $\left(\hat{h}_{i}\right)$ and mean heterosis $(\bar{h})$ for grain yield (GY), plant height $(\mathrm{PH})$, ear insertion height (EI), silking (SIL), popping expansion (PE), and fall armyworm damage at 14 and 21 days after emergence (DAE)

\begin{tabular}{|c|c|c|c|c|c|c|c|c|c|c|c|}
\hline \multicolumn{10}{|c|}{$\hat{\vartheta}_{i}$} & \multirow{2}{*}{\multicolumn{2}{|c|}{$\begin{array}{c}\hat{\vartheta}_{i} \\
\mathbf{D A E}\end{array}$}} \\
\hline \multirow[t]{2}{*}{ Parent } & \multicolumn{2}{|c|}{ GY } & \multirow{2}{*}{$\begin{array}{c}\text { PH } \\
\text { Mean }\end{array}$} & \multicolumn{2}{|c|}{ EI } & \multicolumn{2}{|c|}{ SIL } & \multicolumn{2}{|c|}{ PE } & & \\
\hline & Env1 & Env2 & & Env1 & Env2 & Env1 & Env2 & Env1 & Env2 & 14 & 21 \\
\hline ARZM 13050 & -0.050 & 0.673 & -7.286 & -14.810 & -15.117 & -6.191 & -6.278 & -5.730 & -3.623 & 0.356 & 0.469 \\
\hline URUG 298-Roxo & -0.078 & 0.023 & -21.936 & -20.650 & -23.177 & -7.596 & -8.945 & -1.510 & 1.151 & 0.3213 & 0.316 \\
\hline SAM & -0.322 & -0.285 & -3.166 & -5.090 & -3.727 & -2.432 & -2.945 & 11.157 & 14.711 & 0.127 & 0.326 \\
\hline PARA 172 & 0.224 & -0.329 & -7.441 & 11.020 & -14.557 & 0.404 & 1.722 & -2.843 & -3.573 & -0.857 & -0.091 \\
\hline ARZM 07049 & -0.343 & -0.432 & -2.386 & -5.930 & -3.167 & 6.693 & 4.389 & 0.101 & -0.626 & 0.336 & -0.456 \\
\hline UNB 2U C5 & 0.678 & 0.079 & 1.144 & -4.540 & -13.447 & -5.757 & -3.611 & 16.381 & 15.931 & 0.654 & 0.543 \\
\hline SE 013 & 0.086 & -0.220 & -7.166 & 0.180 & 2.383 & 3.801 & 4.389 & -2.956 & -5.959 & -0.211 & -0.673 \\
\hline VIÇOSA & -0.222 & 0.440 & -6.476 & -14.540 & -15.117 & -3.155 & -0.278 & 9.937 & 9.098 & 0.067 & 0.242 \\
\hline BOZM 260 & -0.387 & 0.228 & 10.934 & 13.240 & 12.383 & 1.014 & 0.389 & -8.953 & -10.849 & 0.067 & -0.091 \\
\hline PR 023 & 0.605 & 0.603 & 19.274 & 19.910 & 33.773 & 4.476 & 4.389 & -5.010 & -7.956 & -0.220 & -0.239 \\
\hline PA 091 & -0.594 & -0.675 & -8.366 & -10.090 & -3.447 & 3.584 & 3.056 & -0.066 & 0.988 & -0.663 & -0.620 \\
\hline BOYA 462 & 0.403 & -0.104 & 32.869 & 31.300 & 43.213 & 5.159 & 3.722 & -10.510 & -9.293 & 0.022 & 0.273 \\
\hline \multirow[t]{2}{*}{$\hat{\hat{\sigma}\left(\hat{\vartheta}_{i}-\hat{\vartheta}_{j}\right)}$} & 0.248 & 0.253 & 8.695 & 7.482 & 7.427 & 1.027 & 1.118 & 1.677 & 2.713 & 0.426 & 0.412 \\
\hline & & & & & $\hat{h}_{i}$ & & & & & & \\
\hline \multirow[t]{2}{*}{ Parent } & \multicolumn{3}{|c|}{ GY } & & PH & \multicolumn{3}{|c|}{ EI } & SIL & & PE \\
\hline & & Env1 & Env2 & & Mean & Env1 & & Env2 & Mean & & Mean \\
\hline ARZM 13050 & & 0.131 & -0.290 & & -4.958 & -7.631 & & -4.782 & -0.194 & & 1.198 \\
\hline URUG 298-Roxo & & 0.123 & 0.016 & & -0.083 & 2.677 & & -1.488 & 1.078 & & -1.001 \\
\hline SAM & & -0.035 & 0.148 & & -1.032 & -0.074 & & -0.269 & 0.017 & & -0.457 \\
\hline PARA 172 & & 0.178 & 0.256 & & 6.438 & -1.464 & & 10.340 & -0.464 & & 0.324 \\
\hline ARZM 07049 & & -0.063 & 0.363 & & 5.234 & 7.985 & & 7.160 & -0.670 & & -1.103 \\
\hline UNB 2U C5 & & -0.188 & -0.162 & & -0.423 & -6.990 & & -2.076 & -0.120 & & 0.249 \\
\hline SE 013 & & 0.015 & 0.004 & & 1.697 & -0.183 & & 4.371 & -0.231 & & -0.985 \\
\hline VIÇOSA & & 0.126 & -0.458 & & 2.722 & -1.212 & & 2.717 & 0.140 & & 0.821 \\
\hline BOZM 260 & & 0.017 & -0.026 & & -7.008 & -1.491 & & -4.394 & 0.203 & & -1.851 \\
\hline PR 023 & & -0.267 & -0.098 & & -5.017 & 1.731 & & -9.519 & 0.087 & & 2.509 \\
\hline PA 091 & & -0.057 & -0.077 & & 5.866 & 6.481 & & 2.786 & 0.521 & & 1.838 \\
\hline BOYA 462 & & 0.020 & 0.325 & & -3.439 & 0.175 & & -4.848 & -0.368 & & -1.542 \\
\hline$\hat{\sigma}\left(\hat{h}_{i}-\hat{h} j\right)$ & & 0.147 & 0.150 & & 5.144 & 4.427 & & 4.394 & 0.635 & & 1.334 \\
\hline $\bar{h}$ & & 0.722 & 0.706 & & 21.970 & 22.417 & & 13.185 & -1.630 & & -0.742 \\
\hline
\end{tabular}


homogeneous, since the 25 best estimates (0.570 - 0.088), among them ARMZ 07049 x SE 013 (0.570), UNB 2U C5 x BOZM 260 (0.468), SAM x PR 023 (0.458), VIÇOSA x PR 023 (0.377), UNB 2U C5 x PR 023 (0.356), and URUG 298Roxo x BOZM 260 (0.333), did not differ from each other.

For these combinations, grain yield was partially explained by the heterotic effect, due to the genetic divergence and complementarity among the varieties. In general, the estimates of the combinations URUG 298-Roxo x BOZM 260 (0.577 and 0.333 in Maringá and Araruna, respectively), ARMZ 13050 x SE 013 (0.573 and 0.274), SAM x BOZM 260 (0.489 and 0.152) were satisfactory in both environments, and reciprocal recurrent selection for this trait is promising.

In relation to $\mathrm{PH}$ and $\mathrm{EI}$, the best combinations were SAM x VIÇOSA(-17,321 and-12,272),ARMZ07049 x BOYA 462 (-11,028 and -11,089), and SE 013 x PR 023 (-11,070 and $-10,376)$, with the lowest combined estimates for the two traits, indicating that dominance effects explained the reduction in plant height.

The combinations with the best $\hat{s}_{i j}$ estimates for GY also had negative estimates for SIL, indicating that the dominance effects associated with earlier genotypes tend to boost the productivity of these genotypes.

There were high $\hat{s}_{i j}$ effect for PE in both environments for the hybrid combination SAM x UNB 2U C5 (6.123 and 3.387, in Maringá and Araruna, respectively), indicating that not only the additive effects of these parents were outstanding, but also the non-additive effects when crossed with other genotypes. Therefore, these varieties can be indicated for both intrapopulational methods and breeding by interpopulational techniques.

In Araruna, the damage caused by fall armyworm could not be assessed, due to the need for insecticide application to control the two stink bug species Dichelops melacanthus and Euschistus heros. According to RozaGomes et al. (2011), D. melacanthus reduces the plant height, number of expanded leaves and root dry weight and causes lesions in the whorl and/or shriveling of the central leaves of the plant, while E. heros causes the same effects, but to a lesser extent.

A significant varietal effect was observed in the first and second evaluation 14 and 21 DAE, respectively, indicating differences in the per se performances between the hybrid combinations of at least two varieties (Table 2). No significant differences were observed 28 DAE.

The results indicated significant differences in heterotic effects for fall armyworm reaction, suggesting distinct genetic systems that would control these differentiated responses at 14 and $21 \mathrm{DAE}$ (Table 2). The entire heterosis was explained by specific heterosis $\left(\hat{s}_{i j}\right)$ at $14 \mathrm{DAE}$ and by mean heterosis $(\bar{h})$ at 14 DAE. The significant effects of mean squares of mean and specific heterosis evidenced genetic divergence among the parental varieties, indicating possibilities of exploring them by means of hybrid synthesis (Kvitschal et al., 2004).

Regarding the evaluation at 14 DAE, the genotype with the best $\hat{\vartheta}_{i}$ was PARA 172, significantly similar to PA 091, PR 023 and SE 013 . These varieties were considered superior, due to the predominance of favorable additive gene effects for the trait. For the non-additive gene effects, expressed by $\hat{h}_{i}$, there were no differences between the parent varieties.

At 21 DAE, as in the previous evaluation, the varieties PARA 172, PA 091, SE 013, and PR 023 performed better than the others, along with BOZM260 and ARMZ 07049, with the best performances for $\hat{\vartheta}_{i}$. With regard to $\hat{h}_{i}$, the varieties did not differ significantly from each other, except for SE 013, which had a significantly worse performance than BOYA 462. Thus, varieties PARA 172, PA 091, SE 013, and PR 023 are promising genotypes for intrapopulation breeding for fall armyworm resistance, due to their superior performance over the others, explained by additive gene effects.

Among the combinations with the best (negative) estimates, the intervarietal hybrids PARA 172 x BOZM 260 and PA 091 x BOYA 462 were the best $(-0.8385$ and -0.8341 , respectively), promising as experimental hybrids and indicated for interpopulation improvement for fall armyworm resistance. Another 24 intervarietal hybrids (0.6196 to -0.0390 ) were similar to the above. Among these, hybrid SAM x UNB 2U C5 (-0.5499), aside from being promising for this trait, was also indicated for interpopulation improvement for PE, the main trait evaluated in popcorn breeding. The findings from Ni et al. (2014) indicated that tropical genetic resources are of great and important value to resistance to fall armyworm and earworm, as well as multiple insects and diseases. Besides these authors support that the relationship among plant defense responses and the environmental conditions and fall armyworm injury rates are likely to be critical in understanding the mechanisms of maize resistance to insect pests, included to fall armyworm, as well as phytopathogen infection, which is crucial to reduce yield and grain quality losses.

Acevedo et al. (2018) results indicated that elicitors in the saliva of fall armyworm stains trigger differential levels of plant defense response affecting caterpillar growth and thus causes influence host plant associations in field conditions. Our results showed that there are promising sources to be using in popcorn breeding programs with target in agronomic traits and popping expansion as well as resistance to fall armyworm. Other researches are necessary to elucidate these mechanisms and better understanding the interactions host plant responses and insects in field conditions. 


\section{CONCLUSIONS}

Variety PR 023 is indicated for intrapopulation improvement for grain yield.

The varieties UNB 2U C5 and SAM are indicated for intrapopulation improvement for popping expansion.

Cross SAM x UNB 2U C5 is indicated for reciprocal recurrent selection for popping expansion.

The varieties PARA 172, PA 091, PR 023 and SE 013 are indicated for intrapopulation breeding and the crosses PARA $172 \times$ BOZM 260 and PA $091 \times$ BOYA 462 and SAM $x$ UNB $2 U$ C5 are indicated for interpopulation breeding for resistance to fall armyworm.

\section{ACKNOWLEDGEMENTS, FINANCIAL SUPPORT AND FULL DISCLOSURE}

The authors are indebted to the Coordination for the Improvement of Higher Education Personnel (Capes), for a scholarship.

Authors declare there is no conflict of interests in carrying the research and publishing this manuscript.

\section{REFERENCES}

Acevedo FE, Peiffer M, Ray S, Meagher R, Luthe D \& Felton GW (2018) Intraspecific differences in plant defense induction by fall armyworm strains. New Phytologist, 218:310-321.

Arnhold E, Mora F, Silva RG, Good-god PIV \& Rodovalho MA (2009) Evaluation of top-cross popcorn hybrids using mixed linear model methodology. Chilean Journal of Agricultural Research, 69:46-53.

Bolson E, Scapim CA, Clovis LR, Amaral Júnior AT \& Freitas ILJ (2016) Capacidade combinatória de linhagens de milho avaliada por meio de testadores adaptados à safrinha. Revista Ceres, 63:492-501.

Cai QS, Wang LL, Yao WH, Zhang YD, Liu L, Yu LJ \& Fan XM (2012) Diallel analysis of photosynthetic traits in maize. Crop Science, 52:551-559.

Cruz CD (2016) Genes Software - extended and integrated with the R, Matlab and Selegen. Acta Scientiarum, 38:547-552.

Cruz CD, Regazzi AJ \& Carneiro PCS (2012) Modelos biométricos aplicados ao melhoramento genético. $4^{\mathrm{a}}$ ed. Viçosa, Universidade Federal de Viçosa. 515p.

Cruz JC, Alvarenga RC, Neto MMG, Viana JHM, Oliveira MF \& Santana DP (2006) Manejo da cultura do milho. Sete Lagoas, Embrapa/Centro Nacional de Pesquisa de Milho e Sorgo. 12p. (Circular Técnica, 87).

Davis FM, Ng SS \& Williams WP (1992) Visual rating scales for screening whorl-stage corn for resistance to fall armyworm. Mississippi, USDA/Agricultural And Forest Experiment Station. 9p. (Boletim Técnico, 186)

Farias CA, Brewer MJ, Anderson DJ, Odvody GN, Xu W \& Sétamou M (2014) Native maize resistance to corn earworm, Helicoverpazea, and fall armyworm, Spodoptera frugiperda, with notes on aflotoxin content. Southwestern Entomologist, 39:411-426.

Gardner CO \& Eberhart SA (1966) Analysis and interpretation of the variety cross diallel and related populations. Biometrics, 22:439-452.
Gonçalves LSA, Freitas Junior SP, Amaral Junior AT, Scapim CA, Rodrigues R, Marinho CD \& Pagliosa ES (2014) Estimating combining ability in popcorn lines using multivariate analysis. Chilean Journal of Agricultural Research, 74:10-15.

Hallauer AR, Carena MJ \& Miranda Filho JB (2010) Quantitative genetics in maize breeding. $3^{\mathrm{a}}$ ed. New York, Springer. 663p.

Kvitschal MV, Scapim CA, Tonet A, Pinto RJB, Retuci VS, Amaral Junior AT \& Braccini AL (2004) Análise dialélica de populações de milho na região noroeste do Paraná, na "safrinha". Revista Ceres, 51:19-32.

Laude TP \& Carena MJ (2014) Diallel analysis among 16 maize populations adapted to the northern U.S. corn belt for grain yield and grain quality traits. Euphytica, 200:29-44.

Luz MLS, Dalpasquale VA, Scapim CA, Braccini AL, Royer MR \& Mora F (2005) Influência da umidade das sementes na capacidade de expansão de três genótipos de milho-pipoca (ZeamaysL.). Acta Scientiarum Agronomy, 27:549-553.

Morais AR, Oliveira AC, Gama EEG \& Souza Junior CL (1991) A method for combined analysis of diallel crosses repeated in several environments. Pesquisa Agropecuária Brasileira, 26:371381 .

Moterle LM, Braccini AL, Scapim CA, Pinto RJB, Gonçalves LSA, Rodrigues R \& Amaral Junior AT (2012) Combining ability of popcorn lines for seed quality and agronomic traits. Euphytica, $185: 337-347$

Ni X, Chen Y, Hibbard BE, Wilson JI, Willimas G, Buntin GD, Ruberson JR \& Li X (2011) Foliar resistance to fall armyworm in corn germplasm lines that confer resistance to root-and earfeeding insects. Florida Entomologist, 94:971-981.

Ni X, Xu W, Blanco MH \& Williams WP (2014) Evaluation of fall armyworm resistance in maize germoplasm lines using visual leaf injury rating and predator survey. Insect Science, 21:541555 .

Paula TOM, Gonçalves LSA, Amaral Júnior AT, Oliveira EC, Silva VQR, Scapim CA \& Lopes AD (2010) Magnitude of the genetic base of comercial popcorn and in recommendation in Brazil. Crop Breeding and Applied Biotechnology, 10:289-297.

Rangel RM, Amaral Júnior AT, Gonçalves LSA, Freitas Júnior SP \& Candido LS (2011) Análise biométrica de ganhos por seleção em população de milho-pipoca de quinto ciclo de seleção recorrente. Revista Ciência Agronômica, 42:473- 481.

Roza-Gomes MF, Salvadori JR, Pereira PRVS \& Panizzi AR (2011) Injúrias de quatro espécies de percevejos pentatomídeos em plântulas de milho. Ciência Rural, 41:1115-1119.

Santos LM, Redaelli LR, Diefenbach LMG \& Efrom CFS (2004) Fertilidade e longevidade de Spodoptera frugiperda (J. E. Smith) (Lepidoptera: Noctuidae) em genótipos de milho. Ciência Rural, 34:345-350.

Scapim CA, Amaral Júnior AT, Vieira RA, Moterle LM, Teixeira LR, Viganó J \& Sandoval Júnior GB (2010) Novos compostos de milho-pipoca para o Brasil. Semina: Ciências Agrárias, 31:321330 .

Solalinde JMQ, Scapim CA, Vieira RA, Amaral Junior AT, Vivas M, Pinto RJB, Mora F \& Viana AP (2014) Performance of popcorn maize populations in South American Avatí Pichingá using diallel analysis. Australian Journal of Crop Science, 08:1632-163. 